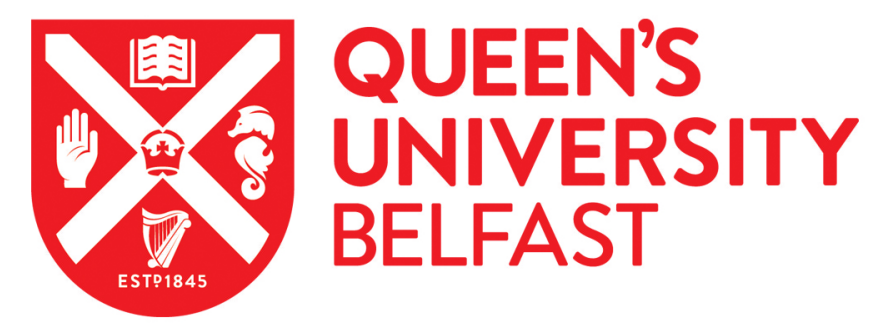

\title{
ACTup: advanced communication training simulation enhanced by actors trained in the Stanislavski system
}

\author{
Sweeney, R., McNaughten, B., Thompson, A., Storey, L., Murphy, P., \& Bourke, T. (2020). ACTup: advanced \\ communication training simulation enhanced by actors trained in the Stanislavski system. BMJ Simulation and \\ Technology Enhanced Learning. https://doi.org/10.1136/bmjstel-2019-000553
}

Published in:

BMJ Simulation and Technology Enhanced Learning

Document Version:

Peer reviewed version

Queen's University Belfast - Research Portal:

Link to publication record in Queen's University Belfast Research Portal

Publisher rights
○ 2020 Authors. Reuse of this manuscript version (excluding any databases,
tables, diagrams, photographs and other images or illustrative material
included where a another copyright owner is identified) is permitted
strictly pursuant to the terms of the Creative Commons Attribution-Non
Commercial 4.0 International (CC-BY-NC 4.0) http://creativecommons.org

General rights

Copyright for the publications made accessible via the Queen's University Belfast Research Portal is retained by the author(s) and / or other copyright owners and it is a condition of accessing these publications that users recognise and abide by the legal requirements associated with these rights.

Take down policy

The Research Portal is Queen's institutional repository that provides access to Queen's research output. Every effort has been made to ensure that content in the Research Portal does not infringe any person's rights, or applicable UK laws. If you discover content in the

Research Portal that you believe breaches copyright or violates any law, please contact openaccess@qub.ac.uk. 


\section{ACTup - Advanced Communication Training Simulation Enhanced by Actors Trained in the Stanislavski System}

Authors: Dr Rory Sweeney ${ }^{1}$ Dr Ben McNaughten ${ }^{1}$, Dr Andrew Thompson ${ }^{1}$, Dr Lesley Storey $^{2}$, Dr Paul Murphy ${ }^{3}$, Dr Thomas Bourke ${ }^{14}$

1. Department of Paediatrics, Royal Belfast Hospital for Sick Children, Belfast, UK

2. Department of Psychology, School of Social Sciences, Birmingham City University, Birmingham, UK

3. Department of Drama, School of Arts, English and Languages, Queen's University Belfast, Belfast, UK

4. Department of Medical Education, Centre for Medical Education, Queen's University Belfast, Belfast, UK

1. Correspondence to: Dr Rory Sweeney, Paediatric Intensive Care Unit, Royal Belfast Hospital for Sick Children, 180 Falls Road, Belfast, BT12 6BE. rsweeney25@gmail.com. Phone 02890633466.

Keywords: Paediatric Simulation, Communication Skills, Patient Death, Paediatrics, Standardized Patients (Actors)

Funding: This research received no specific grant from any funding agency in the public, commercial or not-for-profit sectors.

Competing Interests: None

Contributorship Statement: RS wrote the initial draft, all other authors reviewed and edited before approving the final manuscript.

Word Count: 1,553

\section{Abstract}

\section{Background and Aims}

Strong communication, empathy and interpersonal skills are crucial to good clinical practice. Actors trained in interpretations of the Stanislavski system draw upon their own life experience to develop character. We hypothesized that simulation enhanced by trained actors would be an ideal way for our senior trainees to develop advanced communication skills.

\section{Method}

We developed a communication training course based on challenging situations which occur in paediatrics like child death and safeguarding. Actors were briefed and invited to develop characters that would behave and respond as a parent/carer might do in complex and stressful clinical scenario. Paediatric trainees then participated in 
simulations, with a focus on communication skills. Feedback and debrief were provided by a multi-disciplinary faculty.

\section{Evaluation}

The impact of the course was evaluated by analysis of data collected in focus groups held after the simulation. Trainees noted the actor's ability to respond in vivo to emotive situations and felt it was much more effective than their previous experience of simulation with simulated patients without formal training. Actors were able to offer feedback on aspects of body language, tone and use of language from a nonmedical perspective.

\section{Discussion}

Actors enhanced the realism of the simulations by changing their language and emotional performance in response to the trainee's performance, improving trainee engagement.

\section{Background and Aims}

Strong communication, empathy and interpersonal skills are crucial to good clinical practice. There is clear evidence that poor communication has a negative impact on patient satisfaction and patient outcomes. ${ }^{1,2}$ In paediatrics, empathy is particularly important in discussions around child death and safeguarding. ${ }^{3}$ The Laming report published following an inquiry into the death of Victoria Climbie and the failings of the child protection system concluded that "communication is, of course, crucial to identifying and working effectively with child abuse". ${ }^{4}$ The Royal College of Paediatrics and Child Health in the UK require that all senior trainees be able to "demonstrate effective communication skills in a range of environments and situations with children, young people and families in challenging circumstances". ${ }^{5}$

There is overwhelming evidence that these 'non-technical skills' can be taught. ${ }^{2,6}$ Experiential style methods where students practice and receive feedback are shown to be more effective than classroom-based learning. ${ }^{2}$ Use of simulation training for safeguarding scenarios has received positive feedback from trainees, increasing their confidence in recognising safeguarding issues but not specifically focusing on the communication required in these sensitive situations. ${ }^{7}$

Simulated patients (SP) have been a mainstay of medical education since the $1960 \mathrm{~s}^{8}$ and have been shown to be effective in communication skills training. ${ }^{9}$ The role of SPs has been developing over the last few years and many are now trained actors drawing on a number of different performance techniques. ${ }^{10}$ There are reports of actors performing as simulated family members in paediatric simulation; however our 
experience had been limited to engagement with standardised or untrained simulated family members. ${ }^{11}$

The Stanislavski 'System' is "the most comprehensive study of acting that we possess". ${ }^{12}$ The System was not a fixed methodology but an approach that evolved during Stanislavski's career culminating in The Method of Physical Action which has been subsequently interpreted in many ways by various theatre practitioners. One interpretation encourages actors to draw upon their own life experience to develop characters, as well as imagining what it would be like if they were the character in terms of their emotional life, the so-called "Magic if". ${ }^{13}$ This approach to actor training enhances the realism of a performance and elicits an empathic response from the audience. The system is widely taught in undergraduate curricula for drama students and a course based on this system was being developed by Queen's University of Belfast (QUB) Drama department as a training method for simulated patients. During the course the student actors collaborated with undergraduate medical and social work students and were shown to enrich simulation and facilitate the exploration of empathy, but no collaborations at post-graduate or speciality training level had taken place. ${ }^{14}$

Few paediatric trainees will have an opportunity to take the lead in challenging communication scenarios such as safeguarding and child death. There are reports of actors working as parents in paediatric simulation with a positive impact on the communication skills of the participants. ${ }^{11,15}$ We hypothesized that an advanced communication training simulation course in collaboration with trained actors would be an ideal way for senior trainees to gain experience in some challenging situations encountered in paediatrics.

\section{Method}

The course was aimed at senior paediatric trainees with scenarios based on probable cases that would be encountered as a consultant paediatrician. [Table 1] The scenarios involved emergency clinical simulation with a focus on communication with the family. Six trainees took part in the course. Faculty consisted of paediatric consultants and trainees, a paediatric nurse, children's social workers, clinical psychologist, six actors and the head of the school of drama from QUB. The six actors were selected by the head of drama from QUB as the top performers who had qualified from the drama course and were working professionally. Informed consent was obtained from all participants. NHS research ethics was not sought as advised by the Health Research Authority "Do I need NHS REC approval?' tool." 16

Table 1. 


\section{Scenario Cases}

\begin{tabular}{|l|l|l|l|}
\hline $\begin{array}{l}\text { Morning Sessions } \\
\text { (Safeguarding) }\end{array}$ & $\begin{array}{l}\text { Fabricated Illness } \\
\text { by Salt Poisoning }\end{array}$ & $\begin{array}{l}\text { Acute Head } \\
\text { Trauma }\end{array}$ & $\begin{array}{l}\text { Bruising in Pre- } \\
\text { Mobile Infant }\end{array}$ \\
\hline Afternoon Sessions & $\begin{array}{l}\text { SUDI (Sudden Unexpected } \\
\text { Death in Infancy) }\end{array}$ & $\begin{array}{l}\text { Out-of-Hospital Cardiac Arrest } \\
\text { in 6 year old }\end{array}$ \\
\hline $\begin{array}{l}\text { (Unexpected Deaths) } \\
\text { Tnes }\end{array}$ & & \\
\hline
\end{tabular}

Four of the scenarios occurred in a high-fidelity simulated clinical environment using a SimBaby mannequin which all participants were familiar with. The trainees were expected to initiate emergency management or resuscitation as appropriate and had to communicate with the carers present to elicit the history. The bruising scenario took place in a low-fidelity consultation room as no emergency intervention was required. The participants worked in pairs with one taking the lead in communication with the family. Faculty were present to observe and also to assist with the clinical care and resuscitation if requested.

Two actors were present for each scenario as Mother/Father or Mother/Aunt. They were given character demographics and an overview of how the scenario was to progress but no script was provided. The day before the course the actors were orientated to the simulation environment and piloted the simulations with faculty in the participant's role giving the actors an opportunity to develop the characters and train for the individual scenarios. The pairs of actors performed their scenario three times and were encouraged to behave how they felt their character would respond to the death of a child or accusations of child abuse and vary their responses depending on the trainees' performance.

As the scenarios progressed, the cause of the presentation was revealed. The trainees then had to lead a difficult conversation involving either safeguarding concerns or stopping resuscitation and explain what the next steps are after a child dies. Each scenario lasted 30-45 minutes with 10-15 minutes of simulation and 20-30 minutes of feedback/debriefing.

Immediate feedback was given to the trainees by the multi-disciplinary faculty on the acute medical management and the detail of the communication. The social workers were able to provide insight into managing the next stages of child protection cases and working with the police in cases of SUDI. Throughout their undergraduate training drama students are trained to give feedback on all aspects of performance. The actors therefore gave feedback on body language, tone and use of language from a non-medical perspective giving insight into how they felt as the family member they were portraying in the scenarios. In previous experiences of working with simulated patients this kind of feedback had been lacking. The actors' understanding of the Stanislavski System led to discussions on how professionally 
trainees could use some of the tools of the 'System' such as the 'Magic If' to enable them to empathise better with parents, carers and children going through difficult situations. A debrief involving the whole faculty and participants took place at the end of each session to share and discuss issues raised by the challenging scenarios.

\section{Evaluation}

The impact of the course was evaluated by focus groups conducted by a clinical psychologist who then analysed the transcripts to identify common themes. All six trainees participated in focus groups divided in two groups of 3 .

The themes included their experience of the simulation [Table 2], identification of learning processes [Table 3], affect of clinical knowledge on communication skills, stress management and support for stressful situations.

Trainees compared their previous experience in which untrained healthcare professionals play simulated parents commenting that their colleagues are both too familiar and not sufficiently good actors for the training to be as effective.

Trainees recognised that during the simulations their ability to communicate effectively was impacted when they were uncertain of the clinical information to be relayed such as following the death of a child whether a post-mortem was mandatory. The consultant team were able to provide guidance during the scenarios however it highlighted the importance of clinical knowledge for good communication. Following the course all the trainees reported improved confidence in managing these types of scenarios.

The focus groups provided an opportunity to discuss how trainees cope with stress and what support is available. They acknowledged that they often have to move on quickly after difficult cases and find ways to detach as there are often not formal debrief opportunities within their departments.

Table 2.

\begin{tabular}{|l|l|}
\hline Experience of the Simulated Scenarios & \\
\hline $\begin{array}{l}\text { "I was watching them and a lot of them actually } \\
\text { cried but very appropriately." }\end{array}$ & $\begin{array}{l}\text { "it wasn't that they just had a flat script, they responded } \\
\text { to things and they got angry" }\end{array}$ \\
\hline $\begin{array}{l}\text { "this is close enough to reality, the actors have } \\
\text { been brilliant" }\end{array}$ & $\begin{array}{l}\text { "you felt that they were really the parents that you were } \\
\text { dealing with" }\end{array}$ \\
\hline $\begin{array}{l}\text { "say one of our colleagues is pretending to be the mum and they're upset at the scenario, it's hard to be } \\
\text { comforting in that scenario because you know that this is not real and we're not actors, we're not very good at } \\
\text { it, so it's not realistic enough that you can really get into that emotion" }\end{array}$
\end{tabular}


Table 3.

\begin{tabular}{|c|c|}
\hline Identification of Learning Processes & \\
\hline 1. Ability to practice in a safe space & $\begin{array}{l}\text { "It's good to be pushed to do something that makes you feel } \\
\text { uncomfortable sometimes, because we shy away as registrar } \\
\text { but when you're a consultant you have no choice" }\end{array}$ \\
\hline $\begin{array}{l}\text { 2. Benefits of the feedback from course } \\
\text { tutors }\end{array}$ & $\begin{array}{l}\text { "lots of good tips from the faculty; from experienced } \\
\text { consultants and the trainees who are leading it" } \\
\text { "it wouldn't be as useful without the feedback because once } \\
\text { you do a scenario a lot of it goes out of your head, but if you } \\
\text { sit down and talk about it then bits come back to you and you } \\
\text { think I did that well, or, next time I wouldn't say it like that" } \\
\text { "it is uncomfortable but it's good to get feedback on how you } \\
\text { did because actually day to day we so rarely get feedback on } \\
\text { the spot about how you handled a situation" }\end{array}$ \\
\hline $\begin{array}{l}\text { 3. Benefit of watching others/peers } \\
\text { perform }\end{array}$ & $\begin{array}{l}\text { "you get tips from other people as well, and from seeing other } \\
\text { people doing it" }\end{array}$ \\
\hline $\begin{array}{l}\text { 4. Ability to integrate this with their own } \\
\text { personal experience and previous } \\
\text { observations of senior staff eg mimicking } \\
\text { approach taken by a previous mentor. }\end{array}$ & $\begin{array}{l}\text { "Sometimes you're getting really bad examples of } \\
\text { communication, it's maybe bad to say but it does happen every } \\
\text { now and then. I think taking a little bit from everybody and } \\
\text { cherry-picking the good things and seeing as much as possible } \\
\text { is definitely useful }\end{array}$ \\
\hline
\end{tabular}

\section{Discussion}

When developing a course focussing on stressful situations encountered in paediatrics we had considered whether we could engage real parents who had experience of our scenarios but were felt there was no way to offer them psychological safety if they were being asked to watch a simulation of a situation which their child had been through. By selecting actors identified as the top performers that qualified from a simulated patient training course at QUB. By collaborating with actors while asking the trainees to perform emergency clinical management we were able to simulate highly realistic scenarios thus improving trainee engagement.

The trainees benefitted from feedback on all aspects of their performance with a specific focus on how the communication felt from the point of view of the actors. The actors also gave insight into how their acting training could be taught to medical professionals. They encouraged the trainees to consider how they would feel if they were a parent in the given circumstances to help them understand the range of emotions such as fear, anger, grief that may be distorting the way a parent is interacting with them. 
The course was universally praised with a particular focus on the role the actors played in making the scenarios "very realistic and therefore more challenging". Although this was a small group, we believe the course highlights the benefits of enhancing simulation with trained actors, particularly when replicating the highly emotive situations that frequently occur in paediatrics. The course is now part of the mandatory training for all senior trainees in our region.

\section{References}

1 Laidlaw A, Hart J. Communication skills: An essential component of medical curricula. Part I: Assessment of clinical communication: AMEE Guide No. 51, Medical Teacher 2011, 33:1, 6-8, DOI: 10.3109/0142159X.2011.531170

2 Aspegren K. BEME Guide No. 2: Teaching and learning communication skills in medicine-a review with quality grading of articles, Medical Teacher 1999, 21:6, 563-570, DOI: 10.1080/01421599978979

3 Levetown M. Communicating With Children and Families: From Everyday Interactions to Skill in Conveying Distressing Information. Pediatrics May 2008, 121 (5) e1441-e1460

4 The Victoria Climbie Inquiry: report of an inquiry by Lord Laming.

https://assets.publishing.service.gov.uk/government/uploads/system/uploads/attachment_dat a/file/273183/5730.pdf

5 RCPCH Progress Curriculm - Domain 2 - Professional Skills: Communication. https://www.rcpch.ac.uk/education-careers/training/progress/curriculum\#domain-2--professional-skills-communication-gpc-2

6 UK consensus statement on the content of communication curricula in undergraduate medical education. Martin von Fragstein, Jonathan Silverman, Annie Cushing, Sally Quilligan, Helen Salisbury \& Connie Wiskin on behalf of the UK Medical Education 2008: 42: 1100-1107

7 Hall D, de Munter C, Ninis N, et al. G72 Simulation training in safeguarding children and adolescents: trainees want it, trainees like it and we need to deliver it. Archives of Disease in Childhood 2015;100:A30.

8 Wallace P. "Following the Threads of an Innovation: The History of Standardized Patients in Medical Education". A Humanities Journal for Medicine and the Health Sciences, Volume 13, Number 2, pp 5-28. Autumn 1997

9 Nestel D, Burn CL, Pritchard SA, Glastonbury R, Tabak D. The use of simulated patients in medical education: Guide supplement 42.1 Viewpoint. Med Teach. 2011 //;33(12):1027-9

10 Smith C, Edlington TL, Lawton R, Nestel D. The dramatic arts and simulated patient methodology. In: Nestel D, Bearman M, editors. Simulated patient methodology: Theory, evidence and practice. Chichester, England: Wiley-Blackwell; 2015. p. 39-45

11 Browning DM, Meyer EC, Truog RD, Solomon MZ. Difficult conversations in healthcare: cultivating relational learning to address the hidden curriculum. Acad Med 2007; 82: 905-913. 
12 Benedetti, J. The Art of the Actor: The Essential History of Acting from Classical Times to the Present Day. London, England: Routledge, 2007 p. 109.

13 Benedetti, J. Stanislavski and the Actor: the final acting lessons. London: Bloomsbury, Methuen Drama, 2016 p. 1-13.

14 Walsh IK, Murphy P. 'Healtheatre: Drama and Medicine in Concert', Healthcare 2017; 5(3): 37. https://doi.org/10.3390/healthcare5030037,

15 Meyer EC, Sellers DE, Browning DM, McGuffie K, Solomon MZ, Truog RD. Difficult conversations: improving communication skills and relational abilities in health care. Pediatric Critical Care Medicine 2009; 10 (3): 352-359.

16 Do I need NHS REC review? NHS Research Authority. http://www.hradecisiontools.org.uk/ethics/\#search/ethical +approval+was/_blank 